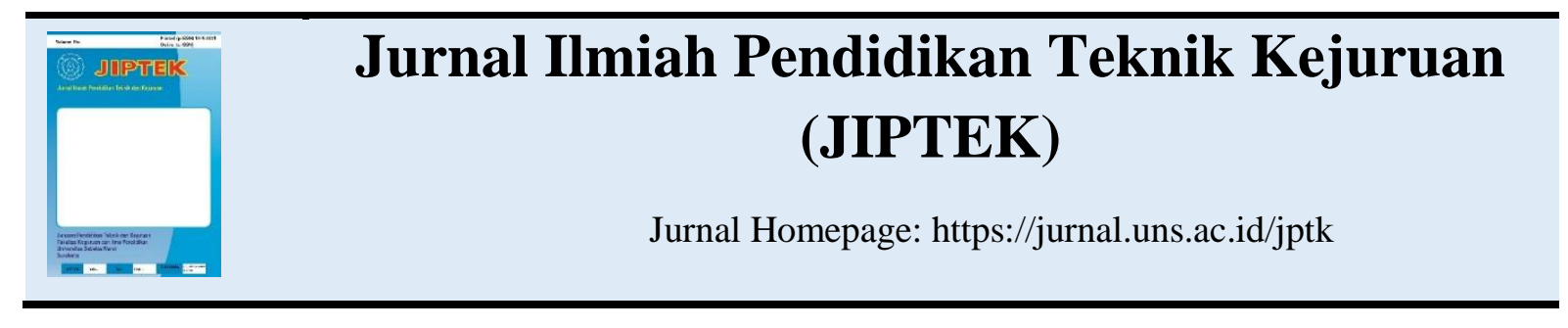

\title{
PENGARUH PENGGUNAAN HYDROGEN ECO BOOSTER TIPE DRY CELL DENGAN VARIASI LARUTAN ELEKTROLIT TERHADAP TORSI DAN DAYA SEPEDA MOTOR 4 TAK BERBAHAN BAKAR PREMIUM
}

\author{
Basti Wahyu Kristanto, Husin Bugis, Ngatou Rohman \\ Program Studi Pendidikan Teknik Bangunan, FKIP, Universitas Sebelas Maret Surakarta \\ Jalan Ahmad Yani 200 Surakarta \\ Email : basswahyoe@gmail.com
}

\begin{abstract}
ABSTRAK
Tujuan penelitian ini adalah (1) Menyelidiki pengaruh penggunaan Hydrogen Eco Booster tipe Dry Cell terhadap torsi dan daya sepeda motor 4 tak berbahan bakar premium. (2) Menyelidiki pengaruh variasi larutan elektrolit pada penggunaan Hydrogen Eco Booster tipe Dry Cell terhadap torsi dan daya sepeda motor 4 tak berbahan bakar premium. Penelitian ini dilakukan di Laboratorium Otomotif Pendidikan Teknik Mesin Fakultas Keguruan dan Ilmu Pendidikan Universitas Sebelas Maret Surakarta dan di PT. Motocourse Technology (MOTOTECH). Penelitian ini merupakan penelitian kuantitatif deskriptif. Desain penelitian yang digunakan adalah desain eksperimen. Sampel penelitian dengan menggunakan sepeda motor Honda Supra X 125 tahun 2013. Alat eksperimen ini menggunakan Hydrogen Eco Booster tipe Dry Cell dengan menggunakan variasi larutan elektrolit air murni, $\mathrm{KOH}$, dan $\mathrm{NaOH}$. Metode pengumpulan data yang digunakan dalam penelitian ini adalah metode eksperimen. Hasil penelitian ini adalah: (1) Penggunaan Hydrogen Eco Booster Tipe Dry Cell berpengaruh terhadap torsi dan daya sepeda motor 4 tak berbahan bakar premium, yaitu diperoleh peningkatan torsi sebesar 0,11 N.m atau $1,16 \%$ dan peningkatan daya sebesar 0,10 HP atau 1,44\% dibandingkan dengan pengujian kondisi mesin standar. (2) Penggunaan larutan KOH 12 gram/liter pada Hydrogen Eco Booster Tipe Dry Cell mempunyai tingkat kenaikan torsi dan daya yang paling tinggi dari variasi perbandingan larutan lainnya. Terjadi peningkatan torsi sebesar 0,08 N.m atau $0,84 \%$ dan peningkatan daya sebesar $0,14 \mathrm{HP}$ atau 1,99\% dibandingkan torsi dan daya pada penggunaan Hydrogen Eco Booster tipe Dry Cell dengan air murni sebagai elektrolit tanpa katalis.
\end{abstract}

Kata kunci: Hydrogen Eco Booster tipe Dry Cell, elektrolisis air, larutan elektrolit, torsi, daya

\section{PENDAHULUAN}

Banyaknya suatu gagasan-gagasan yang bermunculan mengenai energi alternatif salah satu diantaranya adalah menggunakan air, dimana air merupakan sumber daya alam yang dapat diperbaharui dan sangatlah melimpah karena sebagian besar luas permukaan bumi ditutupi oleh air. Pemanfaatan air sebagai energi alternatif sangatlah mungkin karena air 
mengandung struktur kimia $\mathrm{H}_{2} \mathrm{O}$ dan dapat dipisahkan melalui proses elektrolisis menjadi $\mathrm{H}_{2}$ dan $\mathrm{O}_{2}$.

Teknologi elektrolisis air ditemukan oleh Yull Brown, seorang warga negara Australia pada tahun 1974. Istilah brown diambil dari nama belakang Yull Brown yang sampai sekarang dijadikan nama gas dari hasil elektrolisis air yaitu brown gas.

Menurut (Sudirman, 2008: 14) brown gas atau gas oksihidrogen memiliki nilai oktan lebih tinggi dari pada bahan bakar jenis premium maupun pertamax yaitu sekitar 130 sehingga penambahan brown gas diperkirakan mampu meningkatkan tenaga mesin dan menurunkan konsumsi bahan bakar.

Pengembangan elektroliser penghasil brown gas sampai sekarang terus dilakukan penelitian dan pengujian mendalam. Dalam penerapan alat ini menggunakan suatu katalisator yang dicampur dengan air murni, katalisator berperan sebagai pemercepat terjadinya pemisahan unsur hidrogen dengan oksigen dalam air. Banyaknya penelitian yang menerapkan brown gas sebagai penghemat bahan bakar dan meningkatkan performa mesin membuat peneliti semakin terdorong untuk mengembangkannya.

Generator HHO tipe wet cell masih banyak diminati dan digunakan pada saat ini sebagai penghasil brown gas, sedangkan penggunaan dry cell generator akhir-akhir ini lebih banyak diterapkan karena panas dari proses elektrolisis dapat terbuang ke udara luar secara langsung.

Untuk itu dibutuhkan sebuah desain generator HHO tipe dry cell yang optimal untuk aplikasi di masyarakat luas sehingga output dari riset ini adalah Hydrogen Eco Booster tipe Dry Cell dengan variasi larutan elektrolit yang akan diterapkan pada sepeda motor 4 tak berbahan bakar premium dapat meningkatkan torsi dan daya efektif.

\section{Hydrogen Eco Booster}

Berdasarkan penelitian yang dilakukan Saragih (2015) dengan judul Analisis Perbandingan Unjuk Kerja Mesin Sepeda Motor dengan Menggunakan Generator HHO Dry Cell dan Tanpa Menggunakan Generator HHO Dry Cell. Hasil penelitian menunjukkan unjuk kerja mesin sepeda motor menggunakan generator HHO lebih baik dibandingkan tanpa menggunakan generator HHO.

$$
\text { Hydrogen Eco Booster atau biasa }
$$
dikenal dengan sebutan elektroliser adalah alat yang digunakan untuk mengelektrolisis air. Elektroliser terdapat berbagai macam model dan bentuknya. Model Elektroliser secara umum dapat dipisahkan menjadi elektroliser tipe basah (Wet Cell) dan elektroliser tipe kering (Dry Cell).

\section{Tabung Elektroliser}

Tabung elektroliser merupakan 
tempat terjadinya proses elektrolisis untuk menghasilkan brown gas. Tabung elektrolisis harus kuat, kokoh, dan tahan banting.

\section{Elektroda}

Elektroda terdiri dari dua kutub, yaitu katoda (-) dan anoda (+) yang dimasukkan ke dalam larutan elektrolit. Jika elektroda tersebut diberi arus listrik, akan muncul gelembung-gelembung kecil berwarna putih (brown gas). Hal ini menunjukkan bahwa air dan $\mathrm{H} 2 \mathrm{O}$ telah terpisah.

Penelitian yang dilakukan Zhang, dkk. (2010) yang berjudul The Used and Optimization of Stainless Steel Mesh Cathodes in Microbial Electrolysis Cells. Dalam penelitian tersebut menyimpulkan bahwa penggunaan material stainless steel sebagai elektroda memiliki ketahanan terhadap korosi dalam jangka waktu yang cukup lama dan performa yang baik dalam proses elektrolisis dengan penggunaan katalis dalam air.

Material elektroda yang dipilih harus tahan terhadap korosi, menurut Wahyudzin dan Guntur (2012) stainless steel tipe SS 316F, 316L, 316N, 317, 329, dan 304 memiliki ketahanan korosi diberbagai lingkungan.

\section{Larutan Elektrolit}

Menurut Wahyudzin dan Guntur (2012), penambahan larutan elektrolit sebagai katalis pada proses elektrolisis akan menurunkan energi yang dibutuhkan, sehingga laju reaksi pemecahan molekul air menjadi lebih cepat. Pada penelitian ini menggunakan air murni ditambah dengan katalis $\mathrm{KOH}$ dan $\mathrm{NaOH}$.

Berdasarkan percobaan yang dilakukan oleh (Sudirman, 2008: 11), komposisi yang paling ideal antara air murni dengan katalisator adalah 1,5 sendok teh atau sekitar 12 gram berbanding dengan 0,9-1 liter air.

\section{Water Trap}

Alat ini berfungsi sebagai penangkap uap air agar tidak masuk ke dalam ruang bakar. Water trap berisi air murni tanpa katalis sebanyak sepertiga dari isi tabung (Sudirman, 2008: 11).

\section{Cara Kerja Hydrogen Eco Booster}

Cara kerja elektroliser adalah memecah air $\left(\mathrm{H}_{2} \mathrm{O}\right)$ menjadi gas hidrogen hidrogen oksigen (HHO) atau sering disebut sebagai brown gas. Elektroliser dapat menghasilkan gas $\mathrm{HHO}$ dengan cara mengalirkan arus listrik pada elektroda.

Adapun reaksi kimia ikatan brown gas dengan campuran bahan bakar dan udara adalah sebagai berikut:

$\mathrm{HHO}(\mathrm{g})+\mathrm{C} 8 \mathrm{H} 18+9 \mathrm{O} 2 \rightarrow 9 \mathrm{H} 2 \mathrm{O}$

$(\mathrm{g})+4 \mathrm{CO} 2+2 \mathrm{CO}+2 \mathrm{HC}$

\section{Intake Manifold}

Kevakuman di intake manifold ketika katup hisap terbuka dimanfaatkan untuk menginjeksikan brown gas. Agar hisapan tidak terlalu kuat selang dari elektroliser ke 
intake manifold dapat dibuat dengan diameter yang lebih sempit.

Penelitian yang dilakukan oleh Waluyo (2009) yang berjudul Kaji Eksperimen Pengaruh Elektroliser pada Sistem Bahan Bakar Sepeda Motor Satu Silinder C100. Dalam penelitian tersebut memvariasikan pemasangan saluran brown gas, yaitu Before Throttle Valve (BTV) dan After Throttle Valve (ATV). Hasil penelitian pada pemasangan elektroliser ATV terjadi penurunan daya sebesar $0,2 \%$, sedangkan pemasangan elektroliser BTV terjadi peningkatan daya sebesar $0,24 \%$.

Mengacu dari penelitian di atas, untuk pemasangan saluran brown gas di intake manifold diletakkan setelah karburator.

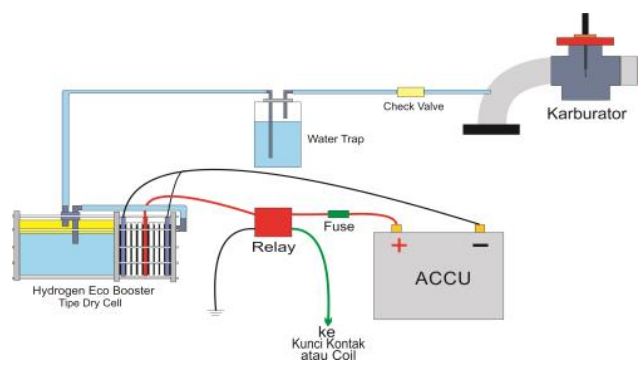

Gambar 1. Skema Instalasi Saluran Elektroliser pada Intake Manifold

\section{Torsi dan Daya}

Menurut Basyirun, Winarno dan Karnowo (2008: 23) torsi adalah ukuran kemampuan mesin untuk melakukan kerja. Kerja yang dimaksud yaitu kemampuan untuk menggerakkan atau memindahkan kendaraan dari posisi diam sampai berjalan.
Menurut Basyirun, dkk. (2008: 24) daya mesin adalah besarnya jumlah energi atau tenaga yang dihasilkan mesin setiap waktunya. Daya dihasilkan dari proses pembakaran di dalam silinder pada motor bakar disebut sebagai daya indikator. Daya tersebut dikenakan pada torak yang bekerja bolak-balik di dalam silinder mesin, terjadi perubahan energi dari energi kimia bahan bakar dengan proses pembakaran menjadi energi mekanik pada torak. Daya indikator merupakan sumber tenaga per satuan waktu operasi mesin untuk mengatasi semua beban mesin (Rizal, 2013: 83).

\section{METODE PENELITIAN}

Penelitian ini merupakan jenis penelitian kuantitatif eksperimen. Penelitian dilakukan diberbagai tempat. Penelitian ini bertujuan untuk mengetahui pengaruh penerapan Hydrogen Eco Booster tipe Dry Cell terhadap torsi dan daya pada sepeda motor 4 tak berbahan bakar premium, untuk perancangan alat Hydrogen Eco Booster tipe Dry Cell dilaksanakan di Laboratorium Otomotif Program Studi Pendidikan Teknik Mesin FKIP Universitas Sebelas Maret Surakarta. Sedangkan untuk pengujian pengaruh terhadap torsi dan daya dilaksanakan di PT. Motocourse Technology.

Populasi dalam penelitian ini adalah sepeda motor 4 tak dengan sampel adalah sepeda motor Honda Supra X 125 tahun 2013. Teknik pengambilan sampel yang 
digunakan adalah teknik simple random sampling. Metode pengumpulan data yang digunakan pada penelitian ini adalah metode eksperimen. metode analisis data yang digunakan adalah penyelidikan deskriptif.

\section{Prosedur Penelitian}

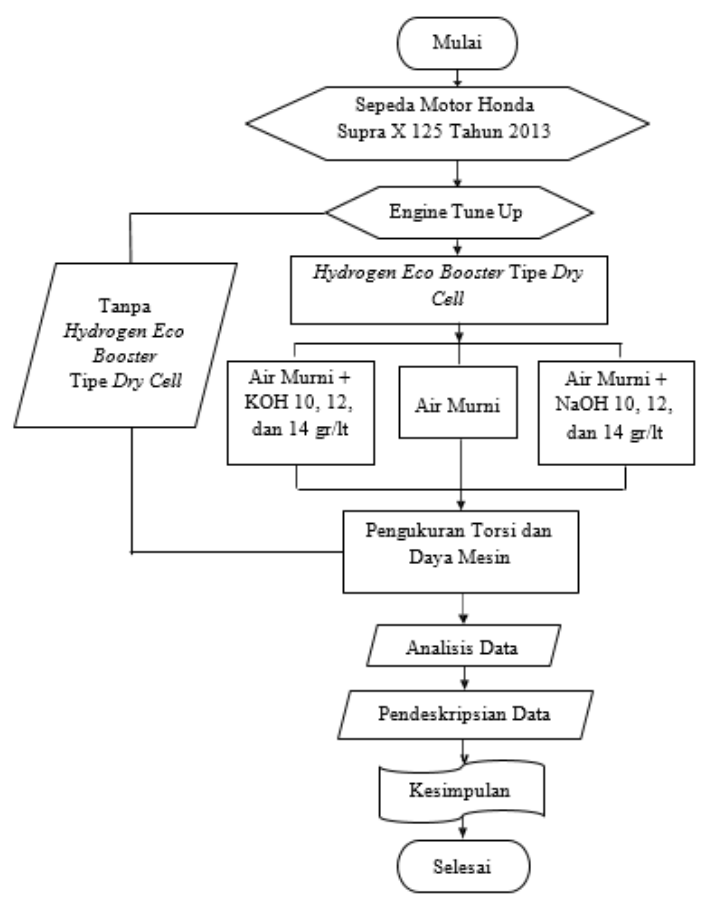

Gambar 2. Prosedur Penelitian

\section{HASIL DAN PEMBAHASAN}

\section{Torsi pada Poros Roda}

Tabel 1. Hasil Pengukuran Torsi (N.m) Maksimum pada Kondisi Standar

\begin{tabular}{ccccc}
\hline Sumber & \multicolumn{3}{c}{ Pengujian Ke- } & Rata- \\
\cline { 2 - 4 } Varian & 1 & 2 & 3 & rata \\
\hline Standar & 9,59 & 9,19 & 9,64 & 9,47 \\
\hline
\end{tabular}

Berdasarkan data hasil pengukuran torsi maksimum sebanyak tiga kali pada sepeda motor Honda Supra X 125 tahun 2013 tanpa menggunakan Hydrogen Eco Booster tipe Dry Cell tersebut, dapat diketahui rata-rata torsi maksimum sebesar 9,47 N.m. 
Berikut gambar pengukuran torsi maksimum:

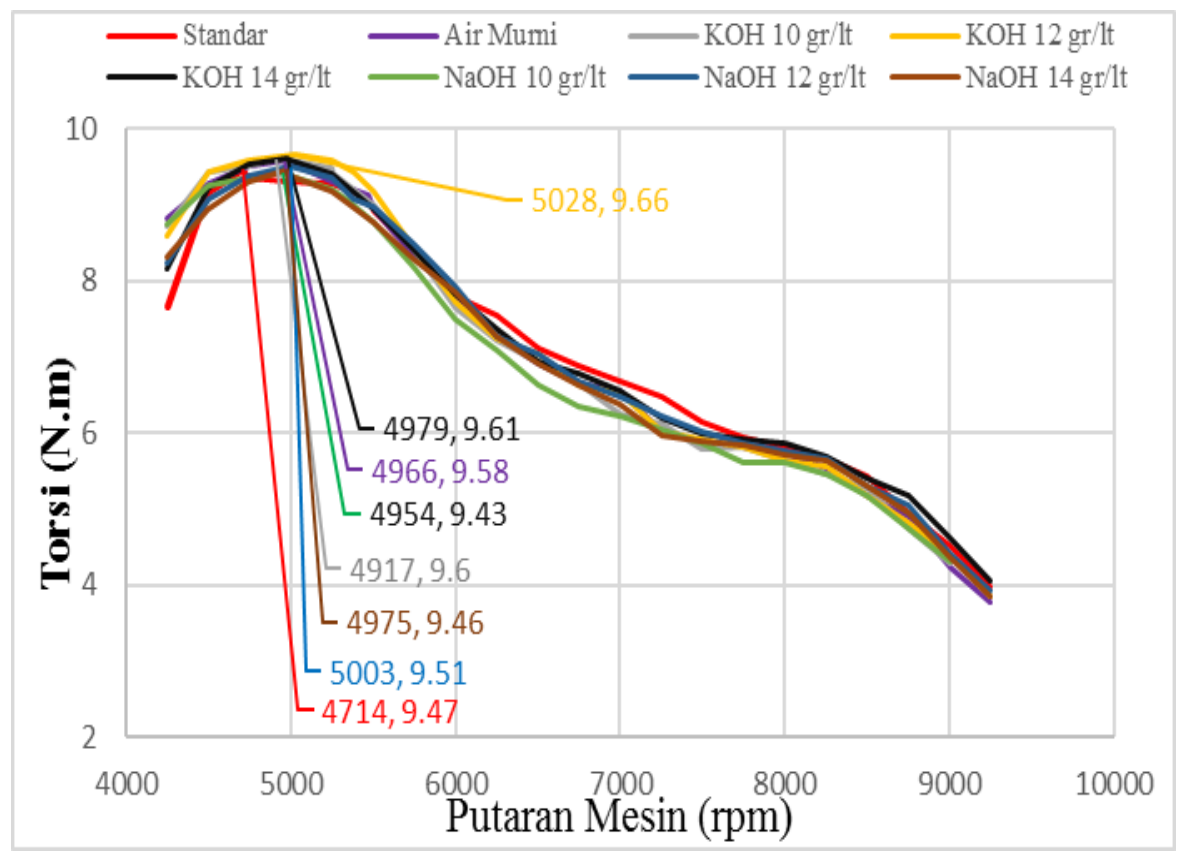

Gambar 3. Grafik Perbandingan Pengukuran Torsi Maksimum

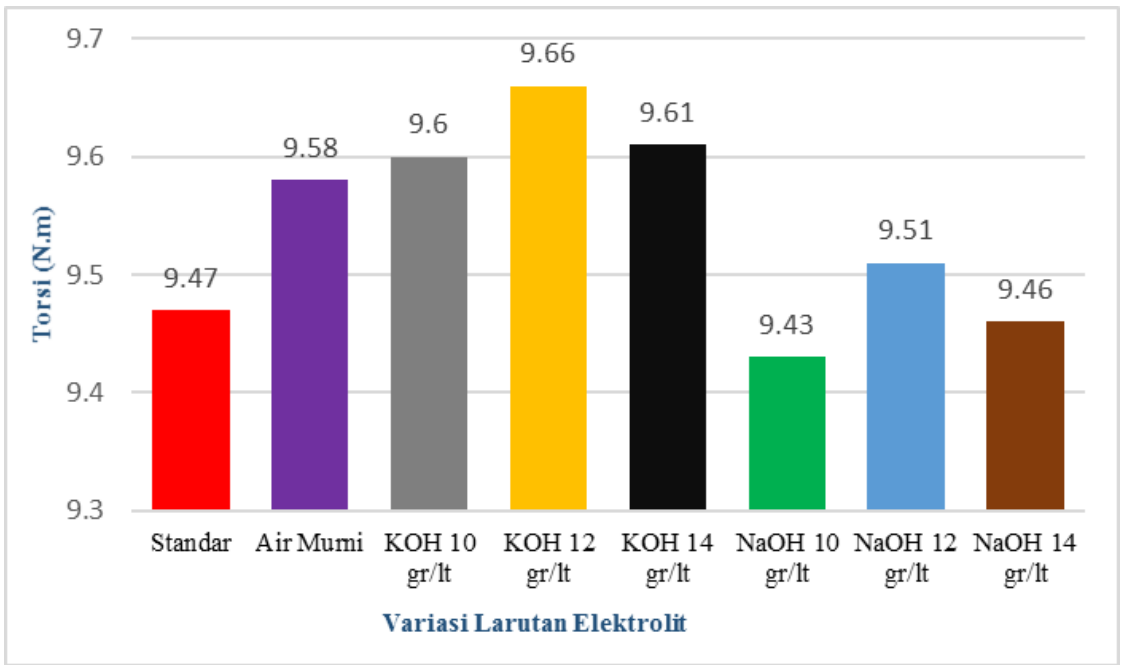

Gambar 4. Histogram Perbandingan Pengukuran Torsi Maksimum

Berdaskan hasil pengujian di atas dapat diketahui bahwa pengujian torsi dengan penggunaan Hydrogen Eco Booster tipe Dry Cell dengan air murni sebagai elektrolit tanpa penambahan katalisator lebih tinggi jika dibandingkan dengan pengujian torsi standar motor Honda Supra X 125 tahun 2013, yaitu dengan torsi maksimal 9,58 N.m pada putaran mesin $4714 \mathrm{rpm}$. Terjadi peningkatan torsi pada poros sebesar 0,11 N.m atau $1,16 \%$.

Gambar 4 menunjukkan torsi tertinggi yang dicapai pada penggunaan Hydrogen Eco Booster tipe Dry Cell dengan variasi larutan elektrolit $\mathrm{KOH} 12$ gram/liter sebesar 9.66 N.m pada putaran mesin 5028 rpm dan 
torsi pada poros roda terendah dengan menggunakan Hydrogen Eco Booster tipe Dry Cell dengan variasi larutan elektrolit $\mathrm{NaOH} 10$ gram/liter sebesar 9.43 N.m pada putaran mesin $4954 \mathrm{rpm}$.

Pada hasil pengujian penggunaan Hydrogen Eco Booster tipe Dry Cell dengan penambahan larutan katalis $\mathrm{KOH} \quad 12$ gram/liter paling tinggi dibandingkan penggunaan katalisator lainnya, yaitu terjadi peningkatan torsi sebesar 0,19 N.m atau $2,01 \%$ dibandingkan pengujian standar. Terjadi peningkatan torsi sebesar 0,08 N.m atau $0,84 \%$ dibandingkan pengujian menggunakan Hydrogen Eco Booster tipe

Dry Cell dengan air murni sebagai elektrolit.

\section{Daya pada Poros Roda}

Tabel 3. Hasil Pengukuran Daya (HP) Maksimum pada Kondisi Standar

\begin{tabular}{ccccc}
\hline \multirow{2}{*}{$\begin{array}{c}\text { Sumber } \\
\text { Varian }\end{array}$} & \multicolumn{3}{c}{ Pengujian Ke- } & Rata- \\
\cline { 2 - 4 } rata \\
\hline Standar & 6,8 & 6,9 & 7,1 & 7,0
\end{tabular}

Berdasarkan data hasil pengukuran daya maksimum sebanyak tiga kali pada sepeda motor Honda Supra X 125 tahun 2013 tanpa menggunakan Hydrogen Eco Booster tipe Dry Cell tersebut, dapat diketahui rata-rata torsi maksimum sebesar 7,0 HP.

Tabel 4. Perbandingan Pengukuran Daya (HP) Maksimum Sepeda Motor Honda Supra X 125 Tahun 2013 dengan Menggunakan Hydrogen Eco Booster Tipe Dry Cell

\begin{tabular}{|c|c|c|c|c|c|c|c|}
\hline \multirow[b]{2}{*}{$\begin{array}{l}\text { Sumber } \\
\text { Varian }\end{array}$} & \multicolumn{7}{|c|}{ Variasi Larutan Elektrolit } \\
\hline & $\begin{array}{c}\text { Air } \\
\text { Murni }\end{array}$ & $\begin{array}{c}\text { Air + } \\
\text { KOH } \\
10 \text { gr/lt }\end{array}$ & $\begin{array}{c}\text { Air + } \\
\text { KOH } \\
12 \text { gr/lt }\end{array}$ & $\begin{array}{c}\text { Air + } \\
\text { KOH } \\
14 \text { gr/lt }\end{array}$ & $\begin{array}{c}\text { Air + } \\
\text { NaOH } \\
10 \text { gr/lt }\end{array}$ & $\begin{array}{c}\text { Air + } \\
\text { NaOH } \\
12 \text { gr/lt }\end{array}$ & $\begin{array}{c}\text { Air + } \\
\text { NaOH } \\
14 \text { gr/lt }\end{array}$ \\
\hline \multirow{3}{*}{ 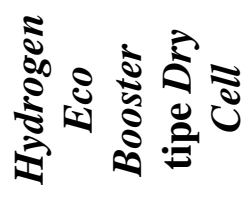 } & 7,2 & 7,0 & 7,1 & 6,9 & 7,0 & 7,0 & 6,9 \\
\hline & 7,0 & 7,1 & 7,1 & 7,1 & 6,8 & 7,1 & 7,0 \\
\hline & 6,9 & 7,1 & 7,3 & 7,0 & 6,8 & 7,0 & 7,0 \\
\hline Rata-rata & 7,03 & 7,07 & 7,17 & 7,0 & 6,87 & 7,03 & 6,97 \\
\hline
\end{tabular}

Berikut gambar perbandingan pengukuran daya maksimum: 


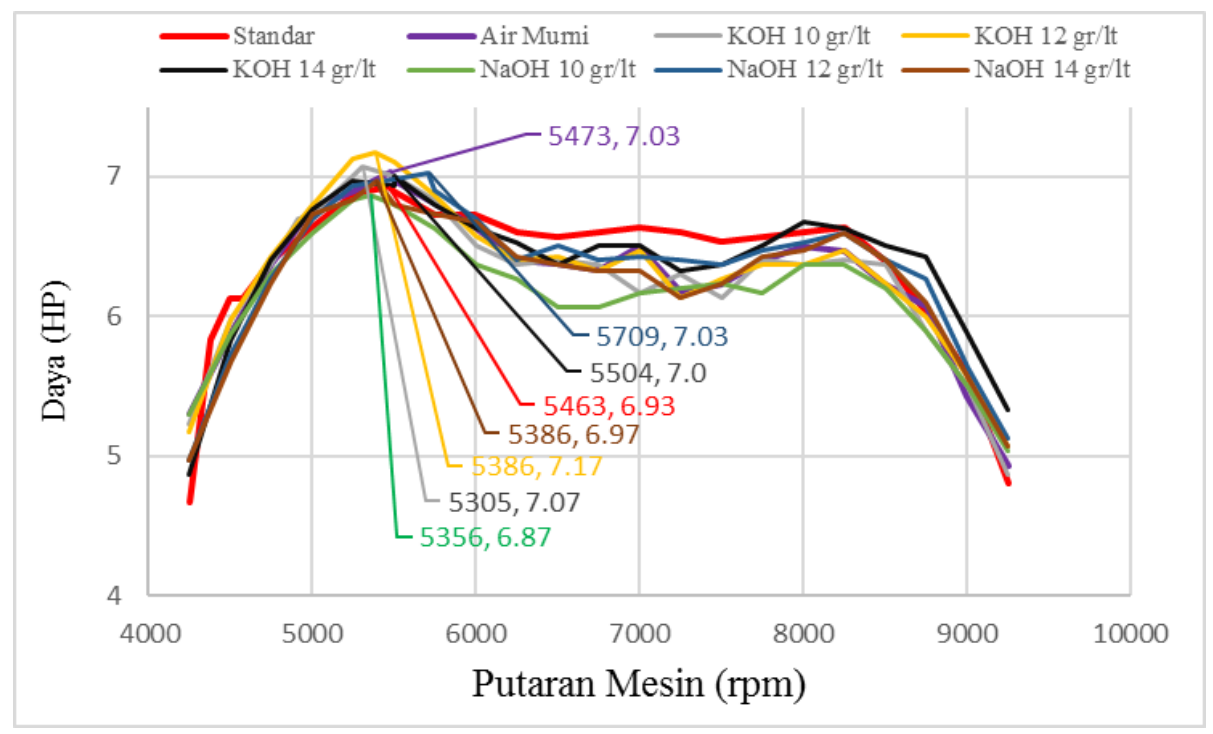

Gambar 5. Grafik Perbandingan Pengukuran Daya Maksimum

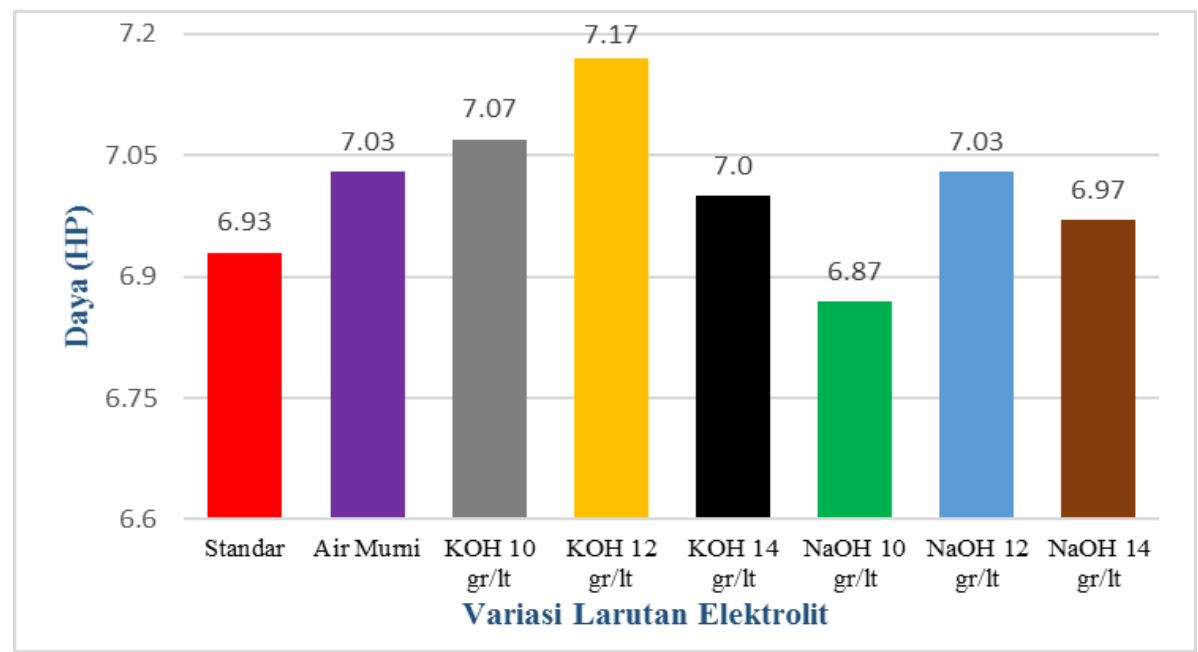

Gambar 6. Histogram Perbandingan Pengukuran Daya

Berdaskan hasil pengujian di atas dapat diketahui bahwa pengujian daya dengan penggunaan Hydrogen Eco Booster tipe Dry Cell dengan air murni sebagai elektrolit tanpa penambahan katalisator lebih tinggi jika dibandingkan dengan pengujian daya standar motor Honda Supra X 125 tahun 2013, yaitu dengan daya maksimal 7,03 pada putaran mesin 5473 rpm. Terjadi peningkatan daya pada poros sebesar $0,10 \mathrm{HP}$ atau $1,44 \%$.
Gambar 6 menunjukkan daya tertinggi yang dicapai pada penggunaan Hydrogen Eco Booster tipe Dry Cell dengan variasi larutan elektrolit $\mathrm{KOH} 12$ gram/liter sebesar 7,17 HP pada putaran mesin $5386 \mathrm{rpm}$ dan daya pada poros roda terendah dengan menggunakan Hydrogen Eco Booster tipe Dry Cell dengan variasi larutan elektrolit $\mathrm{NaOH} 10$ gram/liter sebesar 6,87 N.m pada putaran mesin $5356 \mathrm{rpm}$. 
Pada hasil pengujian penggunaan Hydrogen Eco Booster tipe Dry Cell dengan penambahan larutan katalis $\mathrm{KOH} \quad 12$ gram/liter paling tinggi dibandingkan penggunaan katalisator lainnya, yaitu terjadi peningkatan daya sebesar 0,24 HP atau $3,46 \%$ dibandingkan pengujian standar. Terjadi peningkatan daya sebesar 0,14 HP atau $1,99 \%$ dibandingkan pengujian menggunakan Hydrogen Eco Booster tipe Dry Cell dengan air murni sebagai elektrolit.

\section{SIMPULAN}

Berdasarkan hasil penelitian maka dapat disimpulkan beberapa hal sebagai berikut:

1. Ada pengaruh penggunaan Hydrogen Eco Booster tipe Dry Cell terhadap torsi dan daya sepeda motor 4 tak berbahan bakar premium, yaitu diperoleh peningkatan torsi sebesar 0,11 N.m atau $1,16 \%$ dan peningkatan daya sebesar $0,10 \mathrm{HP}$ atau $1,44 \%$ dibandingkan dengan pengujian kondisi mesin standar.

2. Ada pengaruh penambahan variasi larutan elektrolit terhadap torsi dan daya sepeda motor 4 tak berbahan bakar premium yaitu dengan variasi larutan elektrolit $\mathrm{KOH} 12$ gram/liter, terjadi peningkatan torsi pada poros roda sebesar 0,08 N.m atau $0,84 \%$ dan peningkatan daya pada poros roda sebesar 0,14 HP atau 1,99 \% dibandingkan torsi dan daya pada penggunaan Hydrogen Eco Booster tipe Dry Cell dengan air sebagai elektrolit tanpa katalis.

\section{SARAN}

Berdasarkan hasil penelitian yang diperoleh maka dapat disampaikan saransaran sebagai berikut:

1. Masih perlunya penelitian lebih lanjut mengenai kontruksi Hydrogen Eco Booster tipe Dry Cell,

2. Peningkatan torsi dan daya yang sedikit dikarenakan tidak adanya sistem kontrol, sebaiknya dalam penggunaan Hydrogen Eco Booster tipe Dry Cell ini menggunakan pengontrolan arus ke generator yang disesuaikan dengan putaran mesin.

3. Perlu adanya pengontrolan penginjeksian brown gas ke ruang bakar agar sesuai dengan efisiensi volumetrik silinder dan sesuai dengan kebutuhan mesin, seperti menggunakan jarum suntik.

4. Gunakan perbandingan katalis dengan air murni yang tepat.

5. Disarankan untuk selalu memperhatikan volume air setelah 8 sampai dengan 9 jam pemakaian dalam mengaplikasikan Hydrogen Eco Booster Tipe Dry Cell. 


\section{DAFTAR PUSTAKA}

Basyirun, Winarno, \& Karnowo. (2008). Mesin Konversi Energi. Universitas Negeri Semarang.

Rizal, M.S. (2013). Konversi Energi. Bandung: Direktorat Pembinaan Sekolah Menengah Kejuruan, Direktorat Jendral Pendidikan Menengah, Kementrian Pendidikan dan Kebudayaan.

Saragih, S.A. (2015). Analisis Perbandingan Unjuk Kerja Mesin Sepeda Motor dengan Menggunakan Generator HHO Dry Cell dan Tanpa Menggunakan Generator HHO Dry Cell. Jurnal APTEK, 7 (1), 19 - 26.

Sudirman, U. (2008). Hemat BBM dengan Air. Jakarta: Kawan Pustaka.
Wahyudzin, I., \& Guntur, H. L. (2012). Studi Karakteristik Generator Gas HHO Dry Cell dan Aplikasinya pada Kendaraan Bermesin Injeksi 1300 CC. Jurnal Teknik Pomits, 1 (1), $1-6$.

Waluyo, B. (2009). Kaji Eksperimen Pengaruh Penambahan Elektroliser pada Sistem Bahan Bakar Sepeda Motor Satu Silinder C100. Jurnal Momentum, 5 (1), $30-40$.

Zhang, Y., Merrill, M.D., \& Logan, B.E. (2010). The Used and Optimization of Stainless Steel Mesh Cathodes in Microbial Electrolysis Cells. International Journal of Hydrogen Energy, 35 (2010), 12020 - 12028. 